\title{
Analysis of Pomegranate Value Chain in Kandahar Province of Afghanistan: Issues and Prospects
}

\section{Muhammad Hasham Daqiq ${ }^{*}$}

\begin{abstract}
Pomegranates are one of the most important fruits in the Kandahar province of Afghanistan, which is famous for its pomegranates around the world. Pomegranates play a vital role in the socio-economic life of those who grow them. This study empirically analyzed the value chain of pomegranate production in Kandahar using primary and secondary data. Primary data was collected from 200 pomegranate growers in the Dand, Panjwai, and Daman districts of Kandahar province. These growers were selected using a random sampling method and the data was collected using a structured, pre-tested questionnaire. The secondary data was collected from traders, local collectors, and exporters of pomegranates involving 30 pomegranate selling companies. The value chain analysis shows that from the main four chains of pomegranate production (farmer, collector, trader, and exporter), the main actors are the exporters who process pomegranate and add the greatest value by investing in marketing, shipment, and warehousing and receive highest profit margin among the stakeholders. Exporters of pomegranates to Europe earn an average of 66 Afghani per $\mathrm{kg}$. The next greatest beneficiaries are the growers or farmers who earn an average of 23 AFN on each $\mathrm{kg}$. Local collectors who buy pomegranates from farmers earn the least, at an average of 13 AFN per $\mathrm{kg}$ over the costs of processing and transportation.
\end{abstract}

Keywords: Production, labor, cost, profit margin, farmers, Afghanistan.

JEL Classifications: D4, D46.

\section{Introduction}

Pomegranate production is an important contributor to the Afghan economy. Pomegranates are considered a major fruit crop and a main source of livelihood for thousands of Afghans across many provinces, e.g. Helmand, Ghazni, Farha, Paktia, Kapisa, Wardak, and

\footnotetext{
* PhD Candidate, Capital University of Economics and Business, China. Lecturer in Economics, Kandahar University, Afghanistan. daqiq.hasham@gmail.com
} 
Balkh. The most popular pomegranates are produced in the desert region of Kandahar. Afghanistan is known as the country of the pomegranate fruit, not only because of its production methods, but also because of the high quality of the landraces grown there (Dawrani, 2010).

Since 2009, the government and NGOs have increased their focus on the development of the pomegranate industry in Afghanistan. In 2009, several hundred thousand pomegranate trees were planted, and the nation exported nearly 50,000 metric tons of the fruit to different countries such as Pakistan and India. In the same year, a nearly six million pound juice factory was constructed in Kabul to make the more commercially viable juice concentrate from the fruit (Sadiq, 2010). Furthermore, the Afghan government promoted fruit exports. The US Agency for International Development also provided assistance, which launching the \$6.6 million Kandahar Orchard Project to offer farmers credit for planting new pomegranate trees, particularly on former poppy land (Dawrani, 2010).

The year 2015 was a successful one for Kandahar pomegranates, and according to the report of the Kandahar Chamber of Commerce (KCC, 2015), 7,681 metric tons of pomegranates were exported from Kandahar to different countries, including Pakistan, Tajikistan, India, and even Europe (KCC, 2015).

Data published by the Afghanistan Central Statistic Organization (CSO) in 2017 shows that a total of 99,871 metric tons of pomegranates were produced in Afghanistan on 9,721 hectares of land. Of this, Kandahar produced 72,100 metric tons of pomegranates on 4,825 hectares of land (CSO, 2017). But according to Pajhwok (2018), Kandahar only exported 18,000 metric tons worth USD 4 million (out of 150,000 metric tons produced).

In the last few years there have been some major changes to Kandahar's farming system, including a shift towards multiple cropping and the introduction of new profitable crops. These changes were precipitated by the knowledge brought by Afghans returning from Pakistan and the recent input and support from different international organizations (https: / / afghanag.ucdavis.edu, 2019).

Pomegranate production in Afghanistan has proven a relative success, and the industry has great potential for increased production. However, there is little investment in the sector. Little is known about the 
factors which could be effective at increasing production or which chain of pomegranate production adds more value, in order to increase investment on that chain. This study was designed to help Afghan farmers, investors, the government, and other stakeholders to better understand the production process and which factors can influence pomegranate production.

Specifically, the study seeks to answer the following important questions:

- What are the supply and value chains in the pomegranate sector of Afghanistan?

- What is the natural value chain of the Afghan pomegranate and how it could be improved?

- Which part of the value chain has greatest profitability?

- How can trade and export obstacles be overcome?

\section{Literature review}

This section provides review of the past research related to the supply chain (profitability, investment, and costs) of various exported crops.

Khunt et al., (2003) studied the economics of production, profitability, and marketing cost of pomegranates by analyzing the consumption and disposal pattern of pomegranate in the Bahavnagar district of Saurashtra region of Gujarat. The result of the study showed that marketable surplus was 98.38 percent. Home consumption by relatives and use for religious purposes was found to be insignificant and the deficit due to damage was only 0.83 per cent. The authors also found that majority of the farmers had disposed 59.01 percent of their production in the local market (Khunt et al., 2003).

Nagesh (2006) studied the entrepreneurial behavior of pomegranate growers in Bagalkot district of Karnataka. The main production problems which has been pointed out by the study were, lack of technical know-how, scarcity of labor, pest and diseases, and lack of adequate credit facilities. The marketing problems identified by interviewed farmers included involvement of intermediaries, high costs of packaging material, and high transportation charges, (Nagesh, 2006). 
Koujalgi and Kunnal (1992) calculated the financial feasibility of investment in pomegranate orchards in Bijapur district of Karnataka. The study calculated the net present value for the entire life period of the project to be Rs. 8,283.81. The calculation related to the discounted benefit cost ratio was 1.53. The payback period for the crop was 6.56 years and internal rate of return estimated to be 15.55 percent (Koujalgi and Kunnal, 1992).

Khunt et al. (2003) studied the economics of production and marketing of pomegranates like the Sangli district. The study found that farmers faced a number of problems related to inputs and marketing, including specifically the unavailability of technical training, costly insecticides/pesticides and growth regulators, non-availability of skilled labor at proper times, high wage rates, costly packing material, high commission charges, and lack of efficient market information systems, (Khunt et al., 2003).

Koujalgi et al. (2014) studied the problems faced by farmers marketing pomegranates in Karnataka, India. These were: lack of information about product prices, high transportation costs and other issues related to exporting, lack of maintenance and storage facilities, lack of centers for processing, fruit losses/damage during transportation, high fees of commission, and the lack of guarantee policies for marketing (Koujalgi et al., 2014).

Khan et al. (2008), studying the production of mangos in Pakistan, found that production increased as a result of farm input management practices. Furthermore, the study recommended that the best potential and profitable market for the Pakistan mango is the Middle East (Khan et al., 2008).

More (1999) studied the production of bananas in the Nanded district of Maharashtra, India. Due to the suitability of the climate and awareness among the farmers of better production methods, banana production increased 21 percent. The main reason behind the growth was improved cultural practices and higher use of manures and fertilizers (More, 1999).

\section{Data Design and Collection}

Primary data was collected from pomegranate growers in three major districts: Daman, Dand, and Arghandab, which are the main producers in Kandahar. Furthermore, for the value chain analysis, the 
study required data from pomegranate traders. In some cases, secondary data related to the end consumers and exporters were needed.

The sample consisted of 200 growers of pomegranate and 30 traders who are involved in the processing of the product. The data was collected with the help of a pre-tested structured questionnaire with questions related to all activities included in the value chain: the size of landholdings, cropping patterns, costs of inputs, labor, transportation, and processing, selling price, packaging sorting, and irrigation. In order to reach to the final interview targets, i.e. growers and traders, at the first stage a list of growers in the above mentioned three districts was prepared with help from local agriculture authorities.

The list of pomegranate traders was collected from the Kandahar Chamber of Commerce, and from among them 30 were randomly selected and contacted for interviews. We also interviewed some international dealers via Skype. The steps which enabled us to reach to our target audience are described below.

- Daman, Dand, and Arghandab districts were selected considering their high level of pomegranate production.

- Daman has a total population of 35,402, Dand 45,842, and Arghandab 63,243 for a combined population of 144,487 .

- Considering the share of population in each district, the percentage of the sample to be collected from each district was determined as Daman 24.5\%, Dand 31.7\%, and Arghandab 43.7\%.

- The 200 questionnaires were distributed according to these proportions, giving 88 samples for Arghandab, 63 for Dand and 49 for Daman.

- A list of farmers was prepared based on the areas with pomegranate gardens.

- Among the listed farmers, random sampling was used to choose farmers for interview.

\section{Data Analysis Procedere}

Given the objectives of the study, we applied the methods of Value Chain Analysis to analyze the stages of pomegranate production from grower to consumer, to see which stages of the chain create more 
value for the produced pomegranate and to bring them to the attention of strategic planners and future investment.

Porter's Value Chain and Five Forces Analysis will be undertaken (Porter, 2010). The stakeholder analysis is evaluated to identify the relevant actors involved the pomegranate business in Afghanistan. The analysis covers the purchases of raw material, growing (or producing), manufacturing (or processing), sorting and grading, warehousing, transportation, customer service, demand planning, supply planning, and management of the supply chain.

An industry is attractive when it is profitable and unattractive when it is not profitable. The five forces model is a powerful tool for identifying where power is placed in a business or industry. This is useful because recognizes both the strengths and weaknesses of the current or planned competitive position that the concerned business or industry is considering moving into. Each stage of the map is analyzed to better understand where the power lies and where the opportunities for improvement and investment exist.

Porter's Value Chain explains the five forces which are determinants of the attractiveness and competitiveness of the industry (Porter, 1979). In the practical analysis, the forces which could be useful in the specific case of the pomegranate industry will be used here:

\section{i. Bargaining power of supplier:}

This is the relationship of suppliers with respect to prices, and asks whether the supplier can drive prices by withholding supply. In the case of pomegranates, the specificity or uniqueness of the product counts heavily. When the number of suppliers are few, there will be less competition and the supplier will be more powerful.

\section{ii. Bargaining power of buyers:}

The power of buyer with regard to prices depends on the number of buyers in the market, the cost of changing the buyer, and the terms under which terms they can buy. In the case of pomegranates, the buyers could be local, national, or international, in which case each would have different levels of power to bring down prices.

\section{iii. Inter-competition:}

This force analyzes the number of competitors in the business or industry. In the case of pomegranates, this force is likely weak as 
there are large number of producers and the competition is high. However, the quality of the product, the attractiveness of the product, and the uniqueness of the product differentiate the product from the competitors, which might give rise to market power.

\section{iv. Danger of substitution:}

Here, the existence of substitutes matters. If the customer is able to substitute the product with another, then this force would be weakened. Existence of substitutes is more of a concern in the case of industrial products. However, in the case of pomegranates, this force is less of a concern as there is no direct substitute.

\section{v. Danger of new entry:}

This force refers to barriers to new entry in the market. When it is difficult for new producers to enter to the industry, the position of producers is stronger. In the case of pomegranate production, barriers to entry exist and new producers need a number of years to grow develop pomegranate trees.

Keeping in mind the above five forces, we use Figure 1 to develop the analysis of the pomegranate value chain, in which each step will be analyzed separately. Pomegranates (and other agricultural products) have a different value chain as compared to industrial products. All stockholders who are involved, from production up to end users will be considered in the analysis.

\section{Figure 1: Pomegranate value chain}

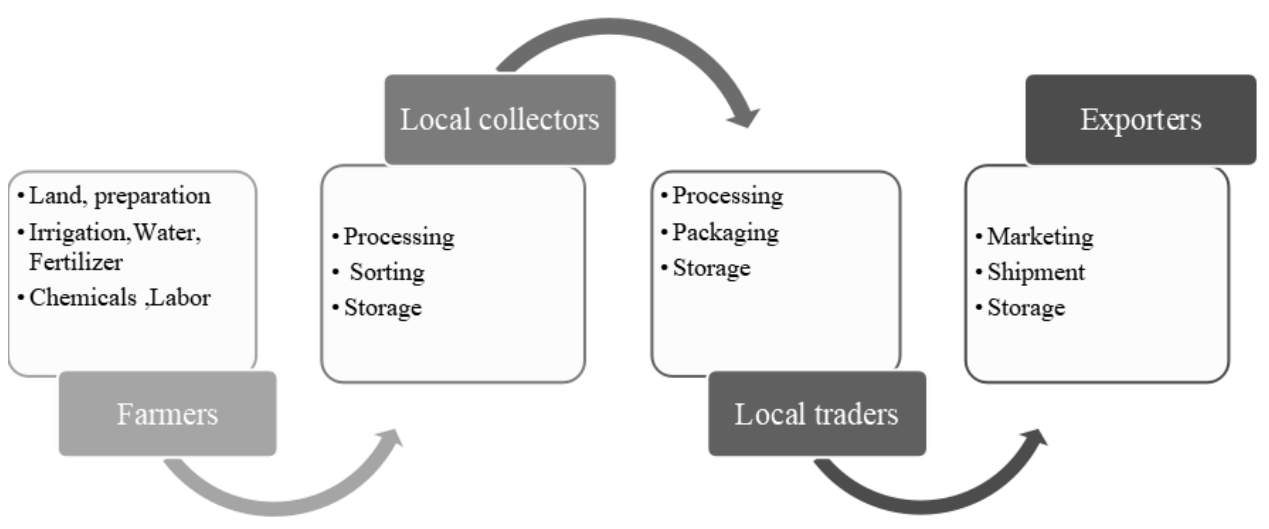




\section{Results}

As mentioned earlier, the study uses primary data collected from three districts of Kandahar province. Before presenting the value chain analysis, we describe some descriptive statistics of the sample in Table 1.

Table 1: Household Heads' Education

\begin{tabular}{lccc}
\hline $\begin{array}{l}\text { Years of } \\
\text { Education }\end{array}$ & Frequency & Percentage & Cumulative Percentage \\
\hline 0 & & & 54.5 \\
2 & 109 & 54.5 & 55.0 \\
3 & 1 & 0.5 & 55.5 \\
4 & 1 & 0.5 & 56.5 \\
5 & 2 & 1.0 & 57.5 \\
6 & 2 & 1.0 & 59.0 \\
7 & 3 & 1.5 & 62.5 \\
8 & 7 & 3.5 & 65.5 \\
9 & 6 & 3.0 & 73.5 \\
10 & 16 & 8.0 & 81.0 \\
11 & 15 & 7.5 & 82.5 \\
12 & 3 & 1.5 & 95.0 \\
14 & 25 & 12.5 & 97.0 \\
15 & 4 & 2.0 & 98.0 \\
16 & 2 & 1.0 & 100.0 \\
Total & 4 & 2.0 & \\
\hline
\end{tabular}

Source: Author's calculations.

From Table 1, 109 of the household heads were illiterate, and only 35 individuals had high school level of education or above. As most of the population lives in rural areas, there is less access to school resulting in a higher illiteracy rate.

Table 2: Land Ownership Status

\begin{tabular}{lccc}
\hline & Frequency & Percentage & $\begin{array}{c}\text { Cumulative } \\
\text { Percentage }\end{array}$ \\
\hline Not own land & 4 & 2.0 & 2.0 \\
Own land & 196 & 98.0 & 100.0 \\
Total & 200 & 100.0 & \\
\hline
\end{tabular}

Source: Author's calculations.

Table 2 shows the ownership status of the pomegranate fields The results show that out of 200 gardens only 4 were owned by someone 
other than the grower, who was paying rent. However, the other 196 gardens were owned by the growers.

Table 3: Number of Laborers

\begin{tabular}{lccccc}
\hline & Frequency & Percentage & $\begin{array}{c}\text { Valid } \\
\text { Percentage }\end{array}$ & $\begin{array}{c}\text { Cumulative } \\
\text { Percentage }\end{array}$ \\
\hline Valid & 1 & 23 & 11.5 & 11.6 & 11.6 \\
& 2 & 78 & 39.0 & 39.4 & 51.0 \\
& 3 & 51 & 25.5 & 25.8 & 76.8 \\
& 4 & 32 & 16.0 & 16.2 & 92.9 \\
& 5 & 11 & 5.5 & 5.6 & 98.5 \\
& 6 & 3 & 1.5 & 1.5 & 100.0 \\
Missing & Total & 198 & 99.0 & 100.0 & \\
Total & System & 2 & 1.0 & & \\
\hline
\end{tabular}

Source: Author's calculations.

Table 3 shows the number of workers working daily in the pomegranate gardens. The most common number of laborers working in a garden is three to four. Fifty-one pomegranate gardens had three people working daily, and 32 gardens had four laborers. Only 23 of the 200 gardens had just one laborer. Importantly, the number of laborers was partially connected to the size of the garden.

\subsection{Value Chain Analysis}

The study of the pomegranate value chain is designed to interpret the entire chain from producer to consumer. Our study focused on farming activity and looked at the prices and costs of other chains to identify the strengths and weaknesses in the chain for potential improvement. The framework of the study is illustrated in Figure 1.

\section{i. Farmers}

Kandahar is characterized agriculturally by pomegranate farming and over the last decade, pomegranate cultivation has spread into several districts of Kandahar.

There are three kinds of pomegranate growers in Kandahar province, the first category being small growers who have $1-100$ pomegranate trees in their garden, the second category is medium 
growers who have $1001-200$ trees, and finally the third category is large growers who have $201-1000$ trees in their garden.

To analyze the farmers chain, we use the activities illustrated in Figure 2.

Figure 2: Farmer and farming activities

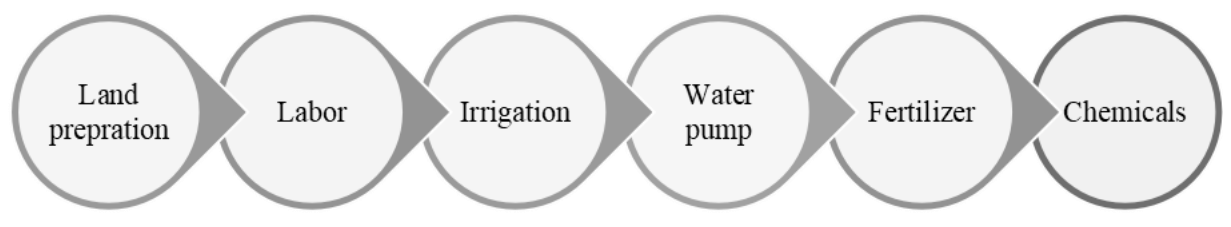

Table 4: Farmers' costs, profits, and sale price of pomegranate, 2020

\begin{tabular}{clc}
\hline Stakeholder & Description of the activities & Average Cost per Kg in AFN \\
\hline & Land Preparation & 2.9 \\
& Labor & 42.9 \\
& Irrigation & 1.2 \\
& Water pump & 1.1 \\
& Fertilizer & 14.7 \\
& Chemicals & 2.8 \\
& Average Total Cost per kg & 65.6 \\
& Average Total Income per kg & 89.04 \\
& Average Net Profit per kg & $\mathbf{2 3 . 4 4}$ \\
\hline
\end{tabular}

Source: Author's calculations.

\section{ii. Local Collectors}

The local collector buys pomegranate from local growers and, after some basic processing, sells to local traders in Kabul city. Regardless of whether these collectors are based inside the villages or outside them, they mostly perform the same tasks as described in Figure 3.

Figure 3: Local collectors and processing activities

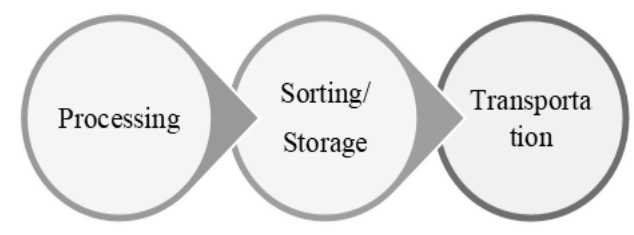


Table 5: Local collectors' costs, profits, and sale price of pomegranate, 2020

\begin{tabular}{|c|c|c|}
\hline Stakeholder & Description of the activities & Average per $\mathrm{Kg}$ in AFN \\
\hline \multirow{7}{*}{ 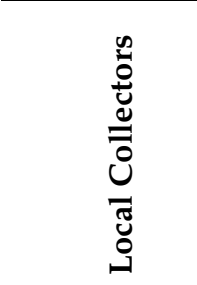 } & Collectors cost of buying & 89.04 \\
\hline & Processing (unstandardized) & 10.4 \\
\hline & Sorting and short-term storage & 7.4 \\
\hline & Transportation to Kabul & 5.15 \\
\hline & Average Total Cost of Collectors per kg & 111.99 \\
\hline & Average Total Income of Collectors per kg & 125 \\
\hline & Average Net Profit per kg & 13.01 \\
\hline
\end{tabular}

Source: Author's calculations.

\section{iii. Local Traders}

There are two types of pomegranate traders in Afghanistan. The first category buy pomegranates from local collectors in Kabul city and either use it to produce juice, syrup sugar, or sell it in the local market to end consumers. The second category are individuals or companies who add value to the pomegranate through standard processing, international standard-based packaging, and preparing it for export. In some cases, these traders are exporters as well, however there are companies who are specialized in exporting. At this stage, we will focus more on processing, packaging, storing of the product for juice or syrup production. It is important to mention that the production of pomegranates is greater than local market demand and when export processes are perturbed, an oversupply of pomegranates in the local market greatly reduces the price.

The value chain for traders is given in Figure 4.

Figure 4: Local trader and processing activities

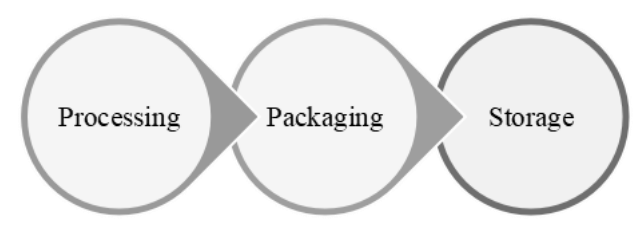


Table 6: Local traders' costs, profits, and sales price of pomegranate, 2020

\begin{tabular}{clc}
\hline Stakeholder & Description of the activities & Average per kg in AFN \\
\hline & Traders cost of buying & 125 \\
& Processing & 1.5 \\
& Packaging (International standard) & 3.29 \\
& Storage & 1.3 \\
& Average Total Cost of Traders per kg & 131.09 \\
& Average Total Income of Traders per kg & 149.8 \\
& Average Net Profit of Traders per kg & $\mathbf{1 8 . 7 1}$ \\
\hline
\end{tabular}

Source: Author's calculations.

iv. Exporter

The main destinations where exports send Afghan pomegranates are Pakistan, Iran, Tajikistan, India, Dubai, Russia, and Europe. Exports increased after developments in packaging and marketing. The profit margins are higher in this part of value chain. The exporters sell the product to local resellers who sell it onward to end consumers. The value chain of this stage can be found in Figure 5.

Figure 5: Exporting and processing activities

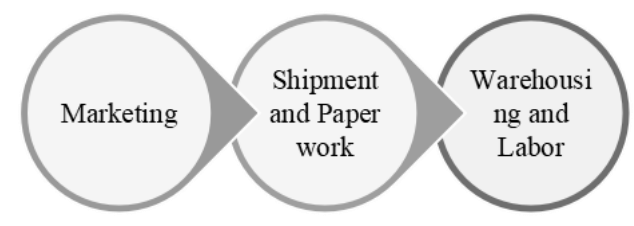

Table 7: Exporters' costs, profits, and sale price of pomegranate, 2020

\begin{tabular}{lcc}
\hline Stakeholder & Description of the activities & Average per kg in AFN \\
\hline & Exporters cost of buying & 149.8 \\
& Marketing & 5.04 \\
& Shipment in special containers and & $12.21+2.26$ \\
& paperwork & 8.81 \\
& Warehousing & 178.12 \\
& Average Total Cost of Exporters per kg & 244.28 \\
& Average Total Income of Exporters per kg to & $\mathbf{6 6 . 1 6}$ \\
\hline
\end{tabular}

Source: Author's calculations. 


\section{Analysis of Value Adding Activity Chain of Pomegranate}

As discussed, there are many stakeholders across the production chain for pomegranates, and each plays a significant role in adding value to the product. Apart from the cost each actor adds to the product, they also receive a marketing or profit margin when they sell the product onward. Table 8 summarizes these prices and costs. In order to analyze the value chain, we need to see the cost and sales price of each individual link in the chain, which will help us to see how much value is added to the product at each stage.

Table 8: Total average prices and costs of stakeholders (2020)

\begin{tabular}{llc}
\hline Stakeholder & \multicolumn{1}{c}{ Description } & Total \\
& Production cost & Average per Kg (AFN) \\
Farmers/growers & Total cost & $\mathbf{6 5 . 6}$ \\
& Selling price & 89.04 \\
& Net Income & $\mathbf{2 3 . 4 4}$ \\
& Buying and selling values & Average per Kg (AFN) \\
& Total cost & $\mathbf{1 1 1 . 9 9}$ \\
Local Collector & Selling price & 125 \\
& Net Income & $\mathbf{1 3 . 0 2}$ \\
& Buying and selling values & Average per Kg (AFN) \\
& Total cost & 131.09 \\
Local Trader & Selling price & 149.8 \\
& Net Income & $\mathbf{1 8 . 7 1}$ \\
& Buying and selling values & Average per Kg (AFN) \\
& Total cost & $\mathbf{1 7 8 . 1 2}$ \\
Exporter & Selling price & 244.28 \\
& Net Income & $\mathbf{6 6 . 1 6}$ \\
\hline
\end{tabular}

Source: Author's calculations.

Recall that in the pomegranate value chain there are four stakeholder groups: Farmers, local collectors, local traders, and exporters.

The first and main actor is the farmer who is a producer of pomegranates using different means of production. The average cost of all 6 activities during the growing period is $65.6 \mathrm{AFN}$ per $\mathrm{kg}$, the average of selling price is $89.04 \mathrm{AFN}$ per $\mathrm{kg}$ and the average net income for one $\mathrm{kg}$ of pomegranate is $23.44 \mathrm{AFN}$. At the same time, the calculation of the average cost of the local collector is $111.99 \mathrm{AFN}$ per $\mathrm{kg}$, the average selling price is 125 AFN per $\mathrm{kg}$ and net income is $13.02 \mathrm{AFN}$ per $\mathrm{kg}$. The third stage is when the local trader buys, processes and sells the product to the exporter. The average cost of a local trader is 131.09 AFN per $\mathrm{kg}$, 
the average selling price is 149.8 AFN per $\mathrm{kg}$, and net income from each $\mathrm{kg}$ pomegranate is about $18.71 \mathrm{AFN}$. The fourth and final stage involves the exporter. The average cost per $\mathrm{kg}$ is $178.12 \mathrm{AFN}$, the average selling price is $244.28 \mathrm{AFN}$ per $\mathrm{kg}$, and the net income per $\mathrm{kg}$ is $66.16 \mathrm{AFN}$.

According to our data, the highest value is added by the exporter, followed by farmers. While each stakeholder is investing in the product before selling it, the investments of farmers and exporters are giving them greater returns than other parts of the value chain. This implies that the government along with other institutions should give more importance to growers and exporters of pomegranate and more investment has to be done in these as they are adding more net value to the product.

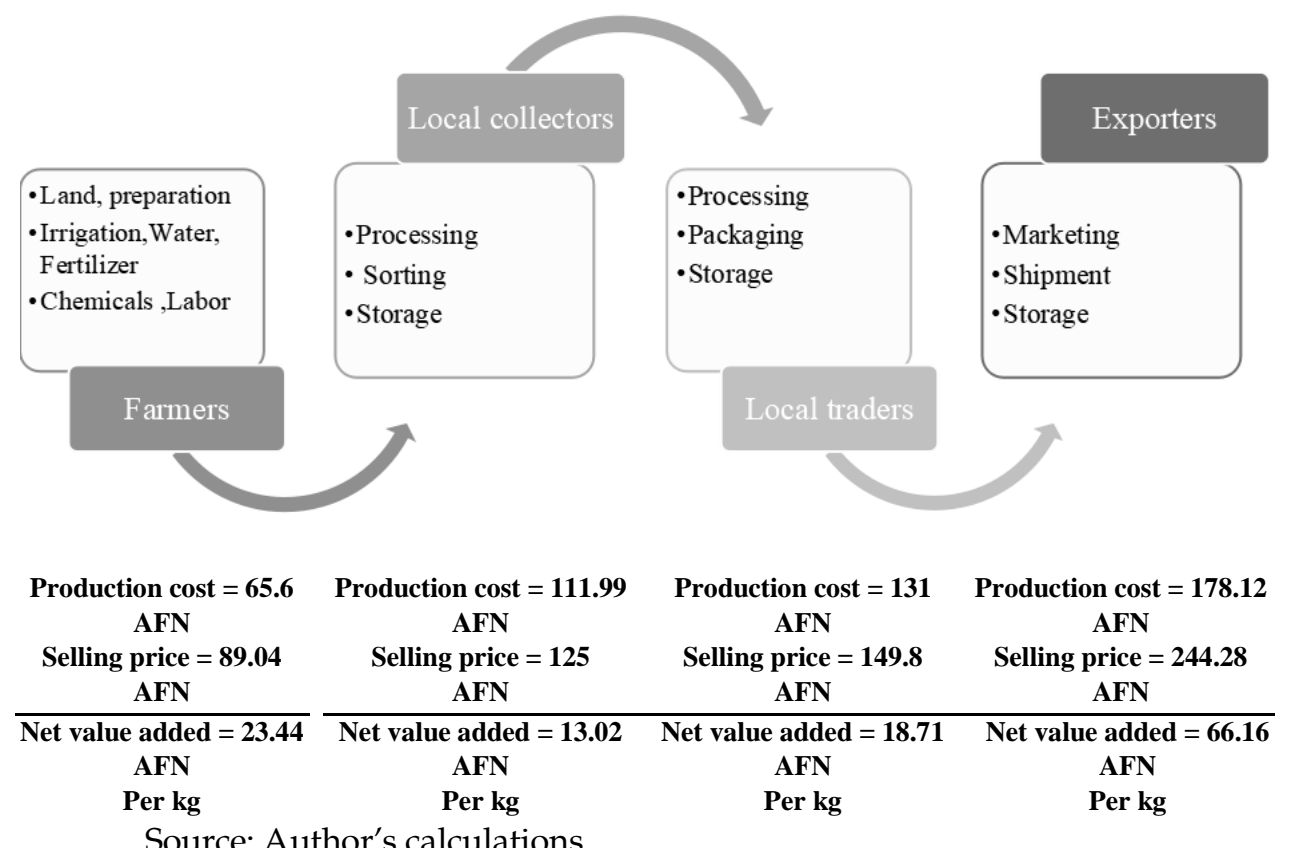

\section{Conclusion and Recommendations}

Pomegranate production is an important contributor to the Afghan economy. Pomegranates are considered a major fruit crop and the main source of livelihood for thousands of Afghans in many provinces, e.g. Helmand, Ghazni, Farha, Paktia, Kapisa, Wardak, and Balkh. As the pomegranate is considered a very important plant for Afghanistan, this study collected primary and secondary data to analyze the value chain of pomegranates and see which chain creates the most value to the product. 
The value chain analysis results show that among the main four chains of pomegranate production, the first and main actor are the exporters who process pomegranate and by investing in marketing, shipment, and warehousing they add the greatest value to the product and receive the highest profits among the stakeholders. Exporters of pomegranates to European market earn an average of 66 Afghani from each $\mathrm{kg}$ of pomegranate. The stakeholder earning the second most from the production of pomegranates are the growers or farmers. They are the main actors in producing pomegranates and after paying the cost of land preparation, chemicals, fertilizers, etc. they earn an average of 23 Afghani per $\mathrm{kg}$ of pomegranate.

The local collectors of pomegranate earn the lowest profit among the stakeholders; even though they make significant efforts to add value to the product, their processing chain is shorter, and they earn less than others involved in chain.

As the result of the study show that exporters and farmers play important roles in adding value to the product. Therefore, it is important that the government and other responsible bodies consider the following points:

- Helping the pomegranate growers have access to modern technology to increase quality in production, processing and sorting according to the needs of the international market. It means the government can use both regulatory tools and technological tools to ensure the standardized quality of pomegranates beginning with the first stages.

- Training should be designed to increase the knowledge of pomegranate growers. It should include training related to the farming, collection, diseases, and seasonal changes of pomegranates. This will boost the quality and processing of pomegranates to help reach international demand.

- Associations and NGOs need to be more involved by providing technical assistance for pomegranate production.

- Farming and collecting tools need to be improved in order to reduce damage to pomegranates.

- Identifying international markets for exporters and signing official trade deals to help in the marketing of pomegranates from Afghanistan. 
- Giving subsidiary land to exporters in order to have central freezing systems in large warehouses to reduce the chances of damaging the product.

- Facilitate short- and medium-term loan systems for exporters along with international insurance systems to enable the exporters to increase their capacity.

- Giving tax incentives to exporters so that they can be internationally competitive. 


\section{References}

Brown, D. (2008). Afghanistan Markets its Pomegranates. The Associated Press. https://www.nbcnews.com/id/wbna27829614

Central Statistics Organization - Islamic Republic of Afghanistan (2017).

Dawrani, N.A. (2010). Afghanistan Investment Support Agency. http://investinafghanistan.af/about-aisa/

Graham, S.A., Hall, J., Sytsma, K., and Shi, S. H. (2005). Phylogenetic analysis of the Lythraceae based on four gene regions and morphology. International Journal of Plant Sciences, 166(6), 995-1017. https://doi.org/10.1086/432631

Halakatti, S.V. (2011). Study on Entrepreneurial Behavior of Pomegranate Growers in Bagalkot District of Karnataka (Doctoral dissertation, UAS, Dharwad).

Nagesh, S. (2008). Study on entrepreneurial behaviour of pomegranate growers in Bagalkot district of Karnataka. M.Sc. (Agri.) Thesis, University of Agricultural Science, Dharwad.

Kandahar Chamber of Commerce (2015). http:/ / www.acci.org.af/

Khan, M., Mustafa, K., Shah, M., Khan, N., and Khan, J.Z. (2008). Forecasting Mango Production in Pakistan an Econometric Model Approach. Sarhad J. Agri, 24(2), 363-370.

Khunt, K.A., Gajipara, H.M., Gadhvi, B.K., and Vekariya, S.B. (2003). Economics of production and marketing of pomegranate. Indian Journal of Agricultural Marketing, 17, 100-107.

Koujalgi, C.B., and Kunnal, L.B. (1992). Input use efficiency in pomegranate orchards in Bijapur district, Karnataka. Indian Journal of Agricultural Economics, 47(3), 527-530.

Koujalgi, C.B., Mundinamani, S.M., Kulkarni, B.S., Mahajanshetty, S.B and Sheikh, M.K. (2014). Of marketing chains for domestic and export purpose of pomegranate in Karnataka. Research Journal of Agricultural Sciences, 4(2), 241-245. 
More, S. (1999). Economics of Production and Marketing of Banana in Maharashtra State. (Doctoral dissertation, University of Agricultural Sciences GKVK Bangalore).

Mustafa, S. (2010). Major deal signed to buy Pomegranate Juice from Afghanistan. Afghan News Journal.

Nagesh, (2006). Study on entrepreneurial behavior of pomegranate growers in Bagalkot district of Karnataka, M.Sc. (Agri.) Thesis, Univ. Agric. Sci., Dharwad, India.

Pajhwok Report (2018). https://www.pajhwok.com/en/2018/10/29/ kandahar-produces-150000-tons-pomegranates

Patil, S.M. (1995). Yield gaps and constraints in groundnut production in Karnataka An economic Analysis. M.Sc. (Agri) Thesis, University of Agricultural Sciences, Dharwad.

Porter, M. E. (1979). Decision Support Tools: Porter's Value Chain. Cambridge University, Institute for Manufacturing.

Porter, M.E. (2010). Strategic Management. Quick MBA, United Kingdom. http://www.quickmba.com/strategy/strategic-planning/

Shilkina, I.A. (1973). On the Xylem Anatomy of the Genus Punica L. Botanicheskii Zhurnal, 58, 1628-1630.

Statistical Year Book, (2019). Afghanistan Central Statistical Organization. https://www.nsia.gov.af:8080/wpcontent/uploads/2020/10/Trade-Statistics-Q2-2020.pdf 


\section{Attachment 1.}

\section{Sample of growers' questionnaire}

\section{د سروب يوبنتنليك}

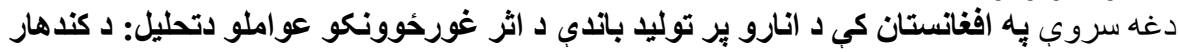

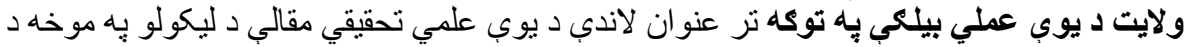

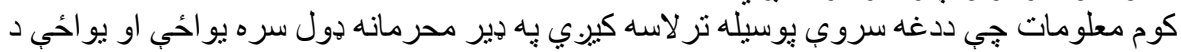

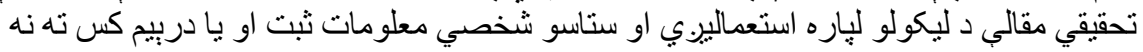

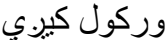
يُه دغه سروب كي ستاسو د ملاتر او كذون نها يوه نرى منته!

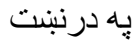
د تحقيق تئيم

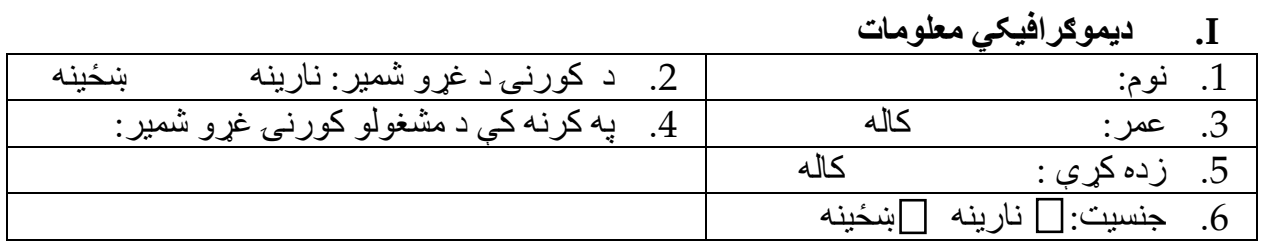

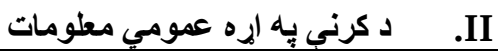

\begin{tabular}{|c|c|}
\hline إنه & 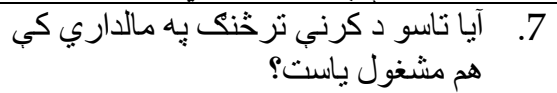 \\
\hline 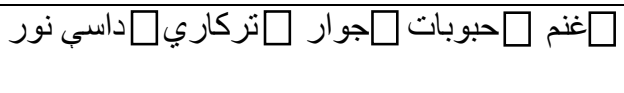 & 8. د انارو ترخنى نوركوم كرنيز \\
\hline & 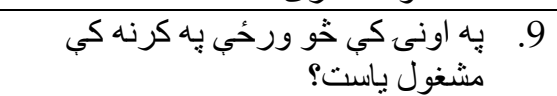 \\
\hline & 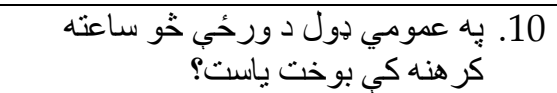 \\
\hline هو & 11. آيا د كر حُمكه مو خِلِه ده؟ \\
\hline نه & 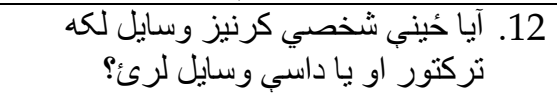 \\
\hline 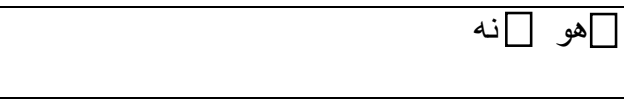 & 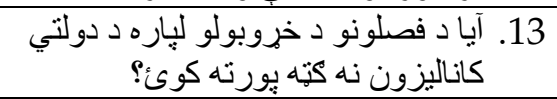 \\
\hline نه & 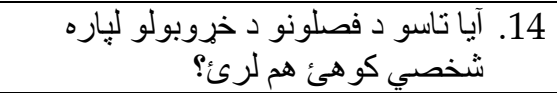 \\
\hline لهو & 15. آيا د كرني ترخنى هو لروم بل دول عايد \\
\hline 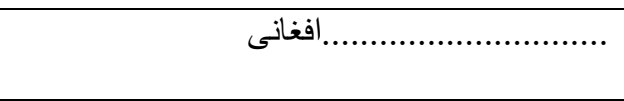 & 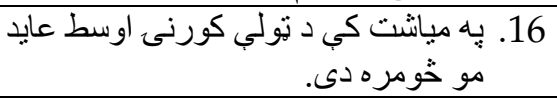 \\
\hline
\end{tabular}




\begin{tabular}{|c|c|c|}
\hline 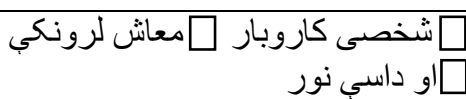 & 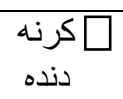 & 17. دو عايد د لاسته راورلو ستري سرجيني \\
\hline
\end{tabular}

III

\begin{tabular}{|c|c|}
\hline & 18. د خوخ كلونو را هيسي د انارو يه كرنه كي \\
\hline 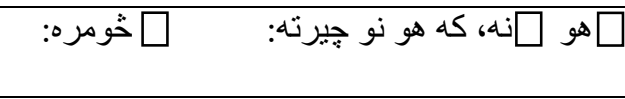 & 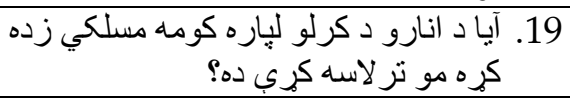 \\
\hline ............. افغانى & 20. تير كال كي مو د انارو د كرلو نه خومره \\
\hline & 21. تير كال كي مو د انارو كرلو ته خومره \\
\hline 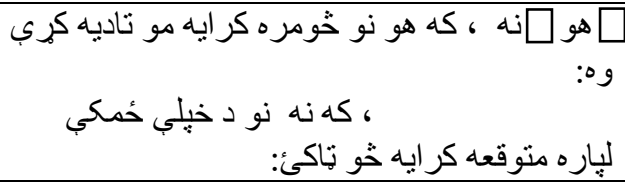 & 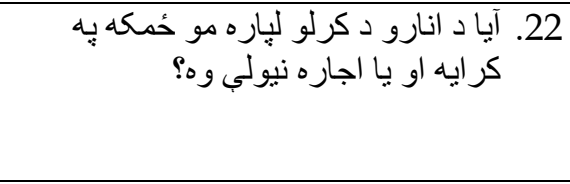 \\
\hline & 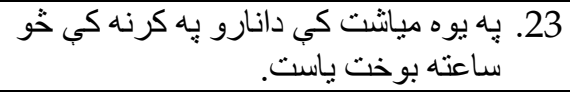 \\
\hline
\end{tabular}

IV

\begin{tabular}{|c|c|}
\hline 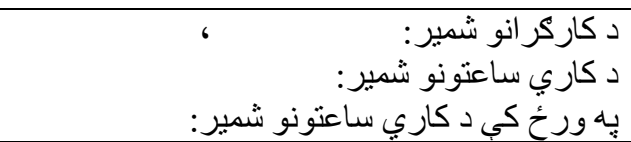 & 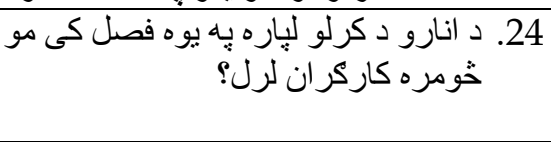 \\
\hline . & 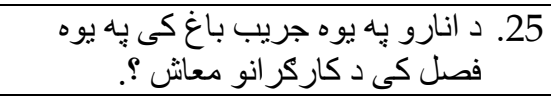 \\
\hline 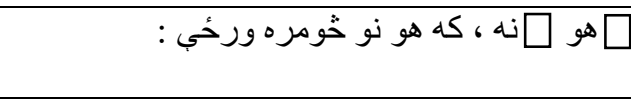 & 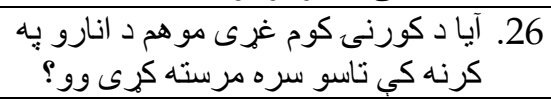 \\
\hline $\begin{array}{r}\square \\
\square\end{array}$ & 27. دم انارو د كرلو لياره مو كوم لكبنتونه \\
\hline ........................... & 28. دد انارو د كرلو لِاره د ونو تعداد خومره \\
\hline 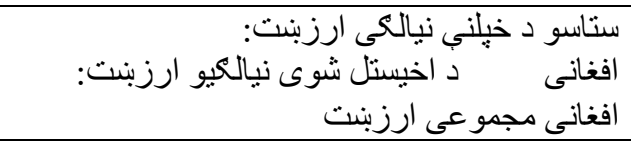 & 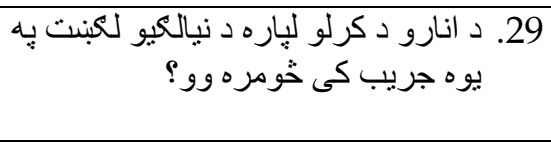 \\
\hline افغانى دزر اعتي آفتونو لياره لكبنتونه: & 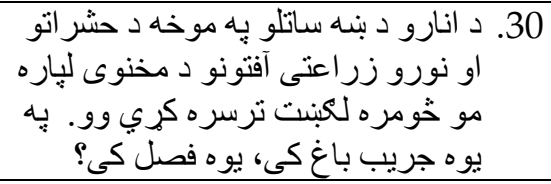 \\
\hline 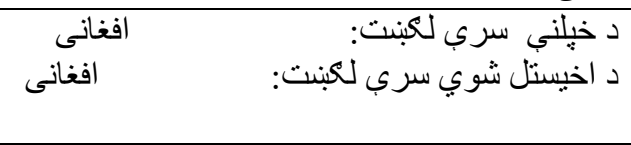 & 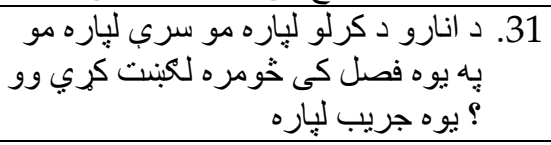 \\
\hline
\end{tabular}




\begin{tabular}{|c|c|}
\hline & 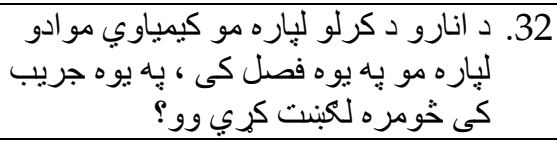 \\
\hline خو هو \دى هنه ، كه هو نو د كلني فرسايش لكبنت مو & 33. آيا تاسو د خيلو وسايلو د فرسايش لكبنت \\
\hline 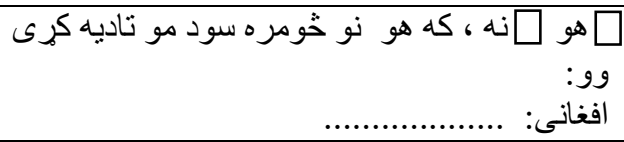 & 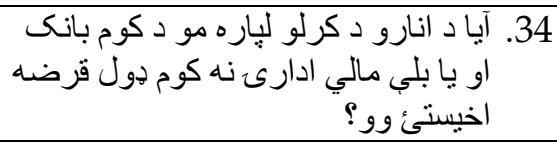 \\
\hline
\end{tabular}

.V

\begin{tabular}{|c|c|}
\hline افغانى........................ & 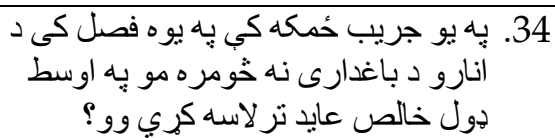 \\
\hline افغغانى........................ & 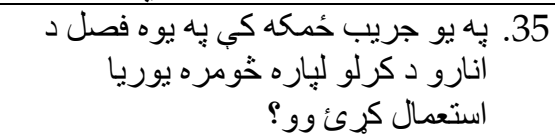 \\
\hline |فغانى.......... & 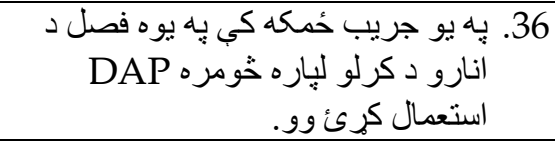 \\
\hline افغانى........... & 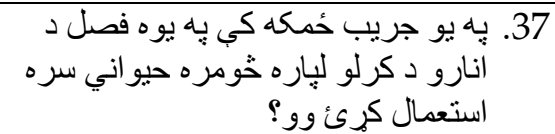 \\
\hline افغانىى..................... & 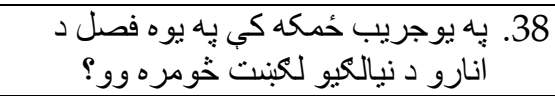 \\
\hline افغانى....................... & 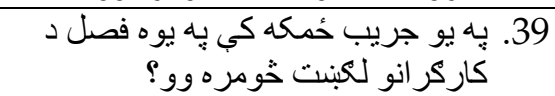 \\
\hline افغانى...................... & 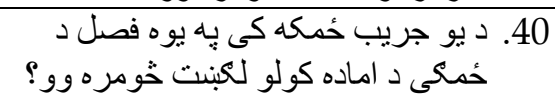 \\
\hline افغانى..................... & 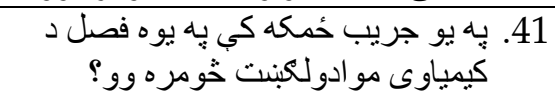 \\
\hline |فغانى.......... & 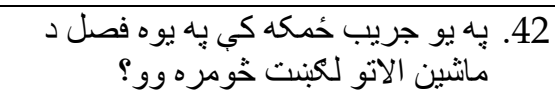 \\
\hline افغانى......................... & 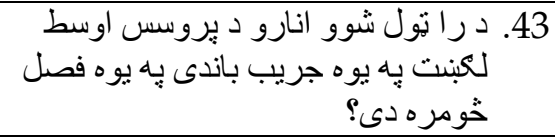 \\
\hline افغانى ........................ & 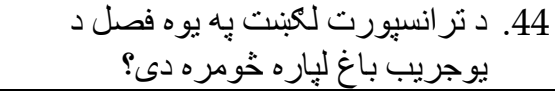 \\
\hline دن يوه جريب انار اندازه يه يو فصل كى .................... & 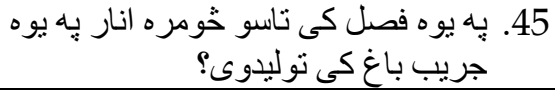 \\
\hline 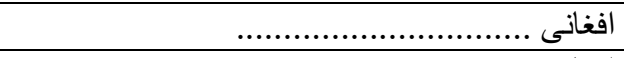 & 46. تاسو ته يو من انار پِه خو تماميزي.ى ؟ \\
\hline 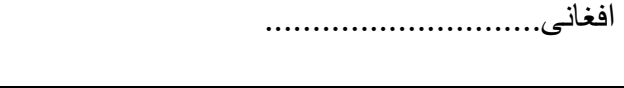 & 47. خاسو يو من انار به خُو تجارانو باندى \\
\hline
\end{tabular}




\begin{tabular}{|c|c|}
\hline 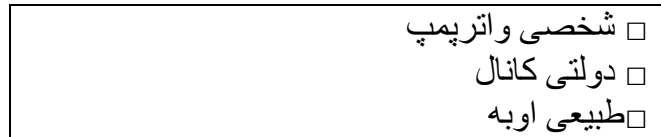 & 48. د باغدارى د اوبو منبع ؟ \\
\hline 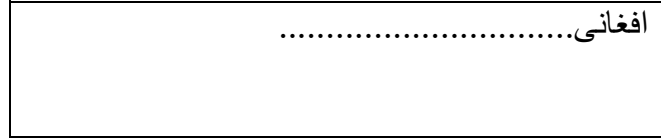 & 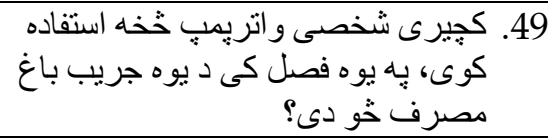 \\
\hline
\end{tabular}

\begin{tabular}{|c|c|c|}
\hline \multirow{2}{*}{\multicolumn{2}{|c|}{ 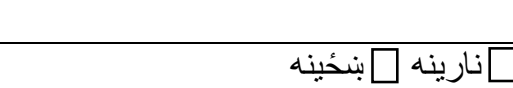 }} & لد كورنى يه إره معلومات \\
\hline & & 1. 1. د كورنى د مشر جنسيت \\
\hline \multicolumn{2}{|c|}{ إنونه } & 2. \\
\hline \multirow[t]{2}{*}{ بنحَينه } & نارينه: & د دورنى د غرو شمير \\
\hline & & 4. هِه كورنى كي مو خومره كسان كاركوي \\
\hline 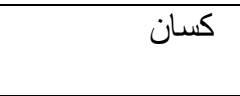 & & 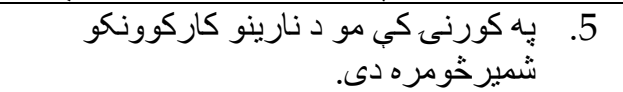 \\
\hline 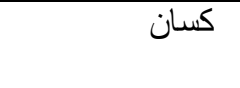 & & 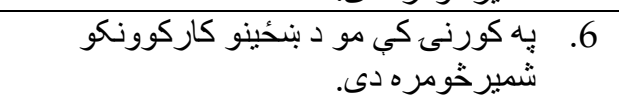 \\
\hline \multicolumn{2}{|l|}{ افغانى } & 7. د كورنى د ورحُخي منوسط عايد مو خومره \\
\hline \multicolumn{2}{|r|}{ افغانى } & 8. د دورنى د ميانشتي متوسط عايد مو خومره \\
\hline \multicolumn{2}{|c|}{ هو } & 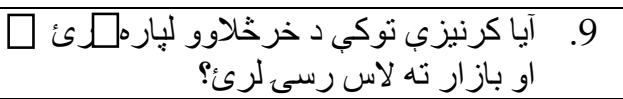 \\
\hline \multicolumn{2}{|l|}{ 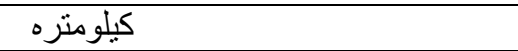 } & 10. بنونئَى مو د كور نه خُومره لري دى. \\
\hline & & 11. آيا د كورنى كوم غرى مو شديده نار] غي \\
\hline
\end{tabular}

